\title{
SLEEP MEDICINE CLINICS
}

\section{FORTHCOMING ISSUES}

September 2020

Telehealth in Sleep Medicine

Jean Louis Pépin and Dennis Hwang, Editors

December 2020

Noninvasive Ventilation and Sleep Medicine Amen Sergew and Lisa Wolfe, Editors

March 2021

Unravelling the Puzzle of Adherence in Sleep Medicine

Jessie P. Bakker, Editor

\section{RECENT ISSUES}

March 2020

Sleep and Performance

Rachel R. Markwald and Anne Germain, Editors

December 2019

Sleep And Driving

Walter T. McNicholas, Editor

September 2019

Precision Sleep Medicine

Susheel P. Patil, Editor 